\title{
REVIEW
}

\section{Advances in the members and biosynthesis of chlorophyll family}

\author{
N.W. QIU, ${ }^{*, \dagger}$, D.C. JIANG ${ }^{*, * * \dagger}$, X.S. WANG ${ }^{*}$, B.S. WANG ${ }^{* * *}$, and F. ZHOU ${ }^{\sharp,+}$ \\ College of Life Sciences, Qufu Normal University, Qufu, 273165 Shandong, China* \\ Shanghai Institute of Nutrition and Health, Shanghai Institutes for Biological Sciences, University \\ of Chinese Academy of Sciences, Chinese Academy of Sciences, 200031 Shanghai, China** \\ Shandong Provincial Key Laboratory of Plant Stress, Shandong Normal University, 250014 Jinan, China*** \\ School of Food Science, Nanjing Xiaozhuang University, 211171 Nanjing, China
}

\begin{abstract}
Chlorophylls are vital for photosynthesis, allowing plants to absorb energy from light for photosynthesis. More than one hundred species of chlorophyll have been identified. Among them, chlorophylls $a, b, c\left(c_{1}, c_{2}\right.$, and $\left.c_{3}\right), d$, and $f$ exist in oxygenic photosynthetic organisms (e.g., higher plants, algae, and cyanobacteria), whereas anoxygenic photosynthetic bacteria possess bacteriochlorophylls $a, b, c, d, e$, and $g$. These chlorophylls have different chemical structures and properties that enable photosynthetic organisms to perform photosynthesis in different environments. All of the chlorophylls are biosynthesized from 3,8-divinyl-protochlorophyllide $a$ by a series of enzymes. The synthetic pathways of chlorophylls have now been basically clarified. This review succinctly summarizes the structures, properties, and synthetic pathways of the chlorophylls.
\end{abstract}

Additional key words: absorption spectrum; chemical bond; porphyrin; side chain; synthetase.

\section{Introduction}

Chlorophylls are the most important and most common pigment molecules in nature and are essential for photosynthesis. They play a central role in the absorption, transmission, and transduction of light energy in photosynthesis. Chlorophylls are widely distributed in green plants, algae, photosynthetic bacteria, and some animals [e.g., Euglena viridis (Bennett and Triemer 2015)]. More than 100 chlorophylls are known today, with the majority discovered in the green bacteria (Scheer 2006).

According to the distribution of chlorophylls in photosynthetic organisms, the chlorophylls can be divided into two categories: the chlorophylls in oxygenic photosynthetic organisms (abbreviated Chls) and the chlorophylls (bacteriochlorophyll) in anoxygenic photosynthetic bacteria (abbreviated BChls) (Chew and Bryant 2007, Harada et al. 2014). Chls $a, b, c\left(c_{1}, c_{2}, c_{3}\right), d$, and $f$ exist in oxygenic photosynthetic organisms (e.g., higher plants, algae, and cyanobacteria), whereas anoxygenic photosynthetic bacteria (e.g., green sulfur bacteria, purple bacteria, filamentous anoxygenic phototrophs, acidobacteria, and heliobacteria) possess BChls $a, b, c, d, e$, and $g$ (Harada et al. 2014). For a long period of time, it was believed that there are only four chemically distinct chlorophylls in oxygenic photosynthetic organisms, namely Chls $a$, $b, c$, and $d$. In 2010, the fifth Chl was discovered from a cyanobacterium in stromatolites from Shark Bay, Western Australia, and named as $\mathrm{Chl} f$ (Chen et al. 2010). In 1948, Harold H. Strain reported a new chlorophyll, namely $\mathrm{Chl} e$, in his unpublished work. Since then, Chl $e$ has been mentioned in a number of monographs from 1950 to 1970 (Allen 1966). However, the properties of Chl $e$ are not clear, and the chemical structure and function are still uncertain. Chl $e$ has not been acknowledged by the scientific community. In order to retain the name for

Received 23 February 2019, accepted 22 July 2019.

${ }^{+}$Corresponding author; e-mail: zfibcas@, 163.com

Abbreviations: 3V-BChlide $a$-3-vinyl-bacteriochlorophyllide $a$; 3V-BChlide $d$-3-vinyl-bacteriochlorophyllide $d$; 8V-Chlide $a$ 8-vinyl-chlorophyllide $a$; ALA - $\delta$-aminolevulinic acid; BChl - bacteriochlorophyll; BChlide - bacteriochlorophyllide; BPheo - bacteriopheophytin; CAO - chlorophyll $a$ oxygenase; Chl - chlorophyll; Chlide - chlorophyllide; COR - chlorophyllide $a$ oxidoreductase; DPOR - dark-operative protochlorophyllide oxidoreductase; DV-PChlide $a-3,8$-divinyl-protochlorophyllide $a$; DVRs - divinyl reductases; LPOR - light-dependent protochlorophyllide oxidoreductase; PChlide $a$ - protochlorophyllide $a$; Pheo - pheophytin; PORs - protochlorophyllide oxidoreductases; Proto-IX - protoporphyrin IX; RC - reaction center.

Acknowledgements: This work was funded by the Postgraduate Education Innovation Project of Shandong Province (SDYY16087), the Key Project of Natural Science Research in Colleges and Universities in Jiangsu Province (19KJA310009), and the Open Fund of Shandong Provincial Key Laboratory of Plant Stress (KLPS2018-01).

†These authors contributed equally to this work. 
the yet poorly characterized $\mathrm{Chl} e$, the newly discovered chlorophyll in stromatolites is named chlorophyll $f$. At the same time, more and more BChls have been discovered, including BChls $a, b, c, d, e$, and $g$. The tentative name and structure of BChl $f$ were proposed in 1975 (Gloe et al. 1975). However, BChl $f$ is only biosynthesized in the mutants of BChl $e$ producing bacteria (Chlorobaculum limnaeum, a green sulfur bacteria) (Vogl et al. 2012) or prepared by modifying Chl $b$ (Tamiaki et al. 2011). In theory, $\mathrm{BChl} f$ should be synthesized in the green sulfur bacteria, but has yet to be discovered in nature.

Although there are many types of chlorophyll, a large part of the synthetic pathways of chlorophylls is the same. All of the chlorophylls are biosynthesized from 3,8-divinyl-protochlorophyllide $a$ (DV-PChlide $a$ ) by a series of enzymes (Chew and Bryant 2007, Harada et al. 2014). DV-PChlide $a$ can be transformed into different chlorophylls through different biochemical pathways. The main pathway of chlorophyll synthesis was discovered in 1948 (Granick 1948). Some chlorophyll synthesis pathways have only been discovered in recent years (Harada et al. 2014, Thweatt et al. 2017), and some are still unclear. This paper summarizes the research on chlorophyll from the aspects of structure, property, function, distribution, and biosynthesis in order to better understand this complex bio-pigment and photosynthesis.

\section{Family members and structure of the chlorophylls}

In addition to Chls and BChls, plants also contain small amounts of pheophytin, protochlorophyllide, etc. Chlorophylls are defined as cyclic tetrapyrroles carrying a characteristic isocyclic five-membered ring (porphyin ring), which are functional in light harvesting or charge separation in photosynthesis (Moss 1988). The properties of chlorophyll members vary with their different structures, so that different photosynthetic organisms can adapt to different environments. Rings and carbon atoms on a chlorophyll structure are commonly numbered according to the IUPAC-IUB nomenclature (Moss 1988) (Fig. 1). The structural characteristics of all chlorophylls are described as follows.

Chlorophyll $\boldsymbol{a}$ and chlorophyll $\boldsymbol{b}$ : The molecular structure of Chl $a$ and Chl $b$ (Fig. 1) is made up of a dihydroporphyrin ring 'head' (known as a chlorin) and a phytol 'tail' (20-carbon atoms hydrocarbon). The chlorin ring is a macrocycle formed by four pyrrole rings and four methene bridges $(=\mathrm{CH}-)$. The magnesium atom is located in the center of the chlorin ring and non-coordinatively bonded to the nitrogen atoms on the pyrrole ring $\mathrm{A}$ and the pyrrole ring $\mathrm{C}$. The magnesium atom carries positive charge, while the nitrogen atoms connected to it carry negative charges. So the 'head' is hydrophilic. The phytol is composed of four isoprene units, which are bonded with the propionic acid on the side chain of the pyrrole ring D by an ester bond. Therefore, the 'tail' is lipophilic. The only difference between $\mathrm{Chl} a$ and $\mathrm{Chl} b$ is that there is a methyl group $\left(-\mathrm{CH}_{3}\right)$ at the $\mathrm{C}-7$ position on the pyrrole ring $\mathrm{B}$ of $\mathrm{Chl} a$, while it is a formyl group (-CHO) on
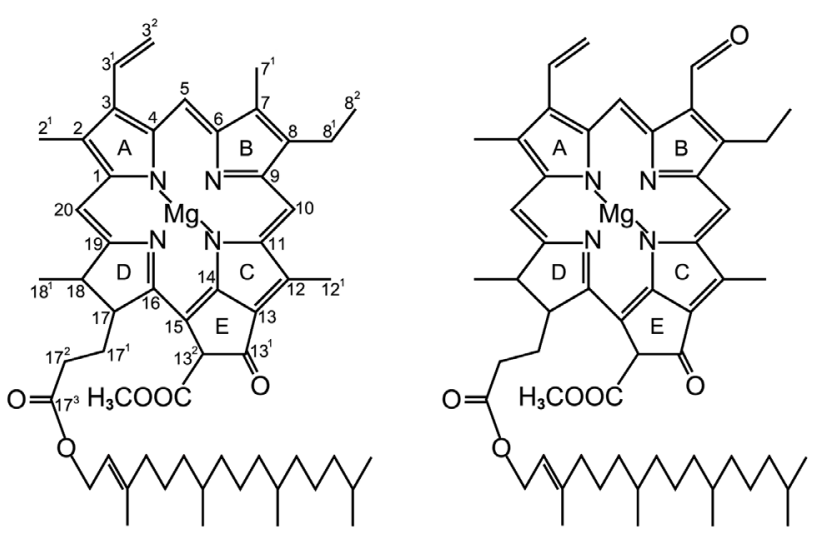

Fig. 1. The structures of chlorophyll (Chl) $a$ (left $)$ and $\mathrm{Chl} b$ (right). Numbering of rings and carbon atoms according to the IUPACIUB nomenclature (Moss 1988).

the same position of Chl $b$ (Fig. 1).

Chlorophylls $c$ : Most members of the Chl $c$ family are porphyins with no phytol 'tail', while the other Chls are dihydroporphyrins (chlorins) with a propionic acid side chain esterified with phytol (Helfrich et al. 2003). There is a carbon-carbon double bond $(\mathrm{C}=\mathrm{C})$ between $\mathrm{C}-17^{1}$ and $\mathrm{C}-17^{2}$ on the side chain of the pyrrole ring $\mathrm{D}$ of Chls $c$, while a carbon-carbon single bond is present at the same position of the other chlorophylls. The second structural feature of Chls $c$ is that there is a double bond between $\mathrm{C}-17$ and $\mathrm{C}-18$ carbons instead of a single bond for the other chlorophylls.

At present, the number of known Chls $c$ has increased to more than ten (Zapata et al. 2006, Xu et al. 2016), among which $\mathrm{Chl} c_{1}$, Chl $c_{2}$, and $\mathrm{Chl} c_{3}$ are the common types of Chls $c$ (Fig. 2). Protochlorophyllide $a$ (PChlide $a$ ) and DV-PChlide $a$, the biosynthetic precursors of chlorophyll, are classified as Chls $c$ in some studies (Helfrich et al. 2003). However, there is a carbon-carbon single bond between $\mathrm{C}-17^{1}$ and $\mathrm{C}-17^{2}$ in their structures, which is the only difference between DV-PChlide $a$ and Chl $c_{2}$ or PChlide $a$ and $\mathrm{Chl} c_{1}$. Chl $c_{1}$ differs from $\mathrm{Chl} c_{2}$ in the structure of the $\mathrm{C}-8$ side chain of the pyrrole ring $\mathrm{B}$, having an ethyl group $\left(-\mathrm{CH}_{2} \mathrm{CH}_{3}\right)$ instead of a vinyl group $\left(-\mathrm{CH}=\mathrm{CH}_{2}\right)$. Chl $c_{3}$, also known as 7-methoxycarbonyl-Chl $c_{2}$, is formed by the substitution of a methyl group $\left(-\mathrm{CH}_{3}\right)$ at $\mathrm{C}-7$ on the porphyin ring $\mathrm{B}$ of $\mathrm{Chl} c_{2}$ by a methoxycarbonyl group $\left(-\mathrm{COOCH}_{3}\right)($ Fookes and Jeffrey 1989).

Chlorophyll $\boldsymbol{d}$ and chlorophyll $\boldsymbol{f}$ : Both Chl $\boldsymbol{d}$ and $\mathrm{Chl} f$ have similar structures to $\mathrm{Chl} a$ (Fig. 3). The replacement of the vinyl group $\left(-\mathrm{CH}=\mathrm{CH}_{2}\right)$ at $\mathrm{C}-3$ on the pyrrole ring A of Chl $a$ with a formyl group ( $-\mathrm{CHO})$ becomes $\mathrm{Chl} d$ (Manning and Strain 1943). The replacement of the methyl group $\left(-\mathrm{CH}_{3}\right)$ at $\mathrm{C}-2$ on the pyrrole ring $\mathrm{A}$ of $\mathrm{Chl} a$ with a formyl group $(-\mathrm{CHO})$ produces $\mathrm{Chl} f$. Therefore, the structural differences of Chl $a, d, f$ lie in the side chains on the pyrrole ring A. Chl $f$ and $\mathrm{Chl} b$ are isomers, only the positions of the formyl and methyl group are different (Chen et al. 2010). 


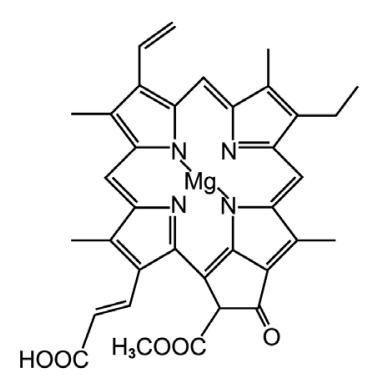

$\mathrm{Chl} c_{1}$

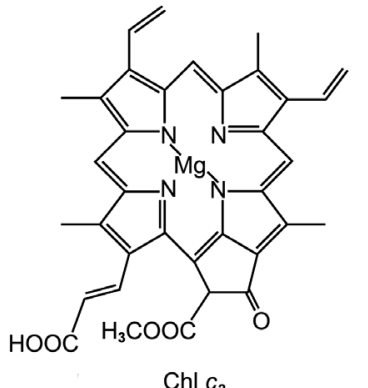

$\mathrm{Chl} \mathrm{C}_{2}$

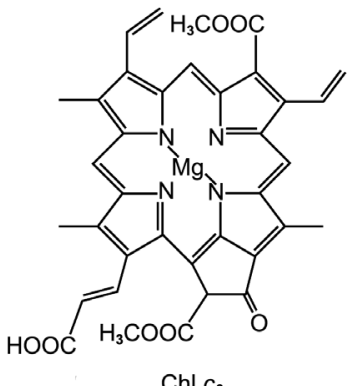

$\mathrm{Chl} c_{3}$

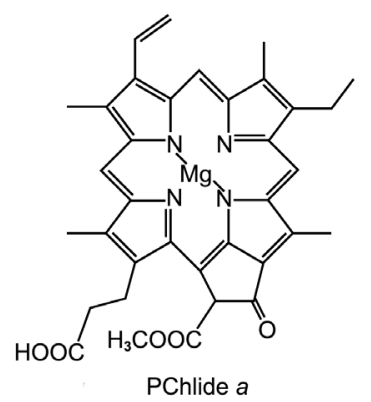

PChlide $a$

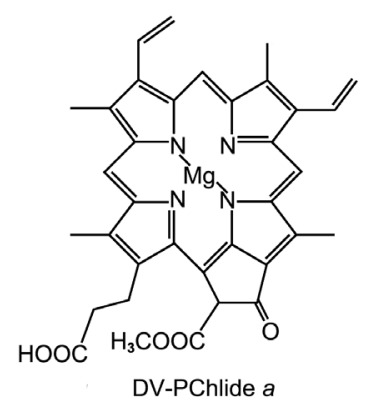

Fig. 2. The structures of chlorophyll (Chl) $c$ members: Chls $c_{1}, c_{2}, c_{3}$, protochlorophyllide $a$ (Pchlide $a$ ) and 3,8-divinyl-protochlorophyllide $a$ (DV-Pchlide $a$ ).
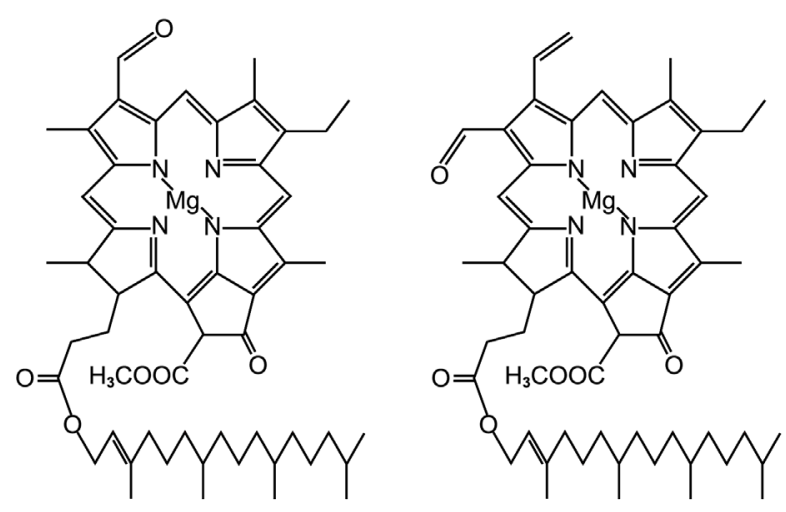

Fig. 3. The structures of chlorophyll (Chl) $d$ (left $)$ and Chl $f($ right $)$.

Pheophytin (Pheo): Chlorophylls contain $\mathrm{Mg}^{2+}$ encased in their porphyrin ring structure. This $\mathrm{Mg}^{2+}$ is active and easily replaced by $\mathrm{H}^{+}$to form pheophytin (Fig. 4). $\mathrm{Mg}^{2+}$ also can be replaced by $\mathrm{Cu}^{2+}, \mathrm{Fe}^{2+}, \mathrm{Zn}^{2+}, \mathrm{Cd}^{2+}, \mathrm{Hg}^{2+}$, and $\mathrm{Ni}^{2+}$ in heavy metal-stressed plants (Taniguchi and Lindsey 2017, Li and Bridwell-Rabb 2019). Pheo can be produced from chlorophyll by the treatment with a weak acid. Pheo serves as the first electron carrier in the electron transfer pathway of PSII in plants.

Bacteriochlorophyll (BChls): According to the number of reduced pyrrole rings, BChls can be divided into two types (Fig. 5). BChls $a, b$, and $g$ have two reduced pyrrole rings $(\mathrm{B}, \mathrm{D})$, and $\mathrm{BChls} c, d, e$, and $f$ have one reduced pyrrole ring (D) (Chew and Bryant 2007, Vogl et al. 2012). So the 'head' of BChls $a, b$, and $g$ belongs to bacteriochlorins (tetrahydroporphyrins) and the 'head' of BChls $c, d, e$, and $f$ belongs to chlorins. In addition, the side chains on the porphyrin ring of each $\mathrm{BChl}$ are also different. For instance, the only difference between $\mathrm{BChl} a$ and $b$ is that $\mathrm{BChl} b$ has an ethylidene $\left(=\mathrm{CH}-\mathrm{CH}_{3}\right)$ instead of an ethyl
$\left(-\mathrm{CH}_{2} \mathrm{CH}_{3}\right)$ at the $\mathrm{C}-8$ side chain. The structures of $\mathrm{BChl}$ $c$ and $e, d$, and $f$ are almost the same, except that BChls $c$ and $d$ have a methyl group $\left(-\mathrm{CH}_{3}\right)$ at the $\mathrm{C}-7$ side chain of the porphyrin ring, and BChls $e$ and $f$ have a formyl group $(-\mathrm{CHO})$ at the same position. BChls $c$ and $e$ have one methyl group $\left(-\mathrm{CH}_{3}\right)$ at $\mathrm{C}-20$ of the porphyrin ring, while BChls $d$ and $f$ do not. The porphyrin ring of BChl $g$ is similar to BChls $a$ and $b$; but its 'tail' is the same as that of BChls $c, d, e$, and $f$. The predominant esterifying alcohol 'tail' of BChls $c, d, e, f$, and $g$ is farnesol (15-carbon atoms), 5 -carbon atoms less than the phytol 'tail' of BChls $a$ and $b$ (20-carbon atoms) (Niedzwiedzki and Blankenship 2010). Many derivatives of BChls $c, d, e$, and $g$ with different side chains and other esterifying alcohols have been identified (Glaeser et al. 2002, Frigaard et al. 2003, 2006; Chew et al. 2007), which are not described here.

\section{Properties, function, and distribution of chlorophylls}

Chl $\boldsymbol{a}$ and Chl $\boldsymbol{b}$ : Chl $\boldsymbol{a}$ (molecular formula: $\mathrm{C}_{55} \mathrm{H}_{72} \mathrm{O}_{5} \mathrm{~N}_{4} \mathrm{Mg}$; molecular mass: $893.48 \mathrm{Da}$; color: blue-green) is the most widely distributed form in all terrestrial plants and oxygenic photosynthetic algae, which can be also found in very small quantities in green sulfur bacteria (an anaerobic photoautotroph) (Eisen et al. 2002). However, Chl $b$ (molecular formula: $\mathrm{C}_{55} \mathrm{H}_{70} \mathrm{O}_{6} \mathrm{~N}_{4} \mathrm{Mg}$; molecular mass: 907.46 Da; color: yellow-green) is distributed in Cyanophyta II, Dinophyta (Dinoflagellates), Euglenophyta, Chlorarachniophyta, Prasinophyceae, Chlorophyceae, green plant plastids (Green et al. 2003). Chl a absorbs light within the violet, blue, and red wavelengths. Its absorption peak wavelengths in $90 \%$ acetone are 430 and $664 \mathrm{~nm}$. Chl $b$ also absorbs light within the violet, blue, and red wavelengths, but its absorption peak in the blue region is longer than that of $\mathrm{Chl} a$, and the absorption peak wavelength in the red region is shorter than that of Chl $a$. The absorption peak wavelengths of Chl $b$ in 


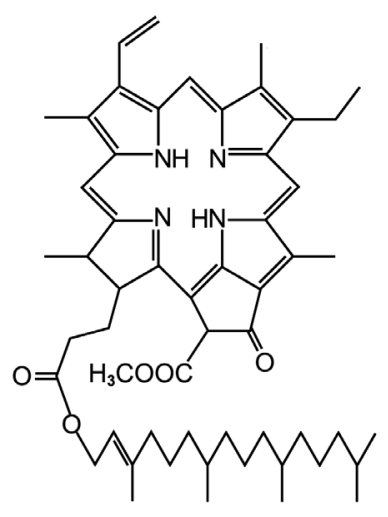

Fig. 4. The structure of pheophytin $a$.

$90 \%$ acetone are 460 and $647 \mathrm{~nm}$. Accessory Chl $b$ and other photosynthetic pigments broaden the spectrum of light absorbed, increasing the range of wavelengths that can be used in photosynthesis (Raven et al. 2005). The addition of $\mathrm{Chl} b$ next to $\mathrm{Chl} a$ can extend the absorption spectrum. In low light conditions, plants produce a higher ratio of $\mathrm{Chl} b$ to $\mathrm{Chl} a$, increasing the photosynthetic yield (Björkman 1981, Esteban et al. 2015). The Chl b-deficient wheat mutant has a decreased photosynthetic function and is more sensitive to heat stress (Brestič et al. 2016). Both Chl $a$ and Chl $b$ can transfer the captured light from one pigment to the next as the resonance energy, until reaching the dimeric $\mathrm{Chl} a$ molecule in the reaction center (RC). These dimeric Chl $a$ molecules are located in both PSII and PSI, known as P680 for PSII and P700 for PSI (Ishikita et al. 2006). Chl $a$ is required for most photosynthetic organisms (except for some anaerobic photosynthetic bacteria), because it is the only pigment in their RCs that converts light energy into electrical energy and participates in photosynthetic electron transport (Björn et al. 2009).

Chl $c$ : Chls $c$ are blue-green, absorbing red light and blueviolet light. Compared to $\mathrm{Chl} a$ and $b$, the light absorption peak wavelength of Chls $c$ in the red region is shorter, the absorption peak wavelength in the blue region is between that of Chl $a$ and Chl $b$. The members of the Chls $c$ family are widely distributed in the golden-brown eukaryotic algae and the chromophytes. Together with $\mathrm{Chl} a$ and carotenoids, Chls $c$ function as light-harvesting pigments (Zapata et al. 2006).

Chl $c_{1}$ (molecular formula: $\mathrm{C}_{35} \mathrm{H}_{30} \mathrm{O}_{5} \mathrm{~N}_{4} \mathrm{Mg}$; molecular mass: $610.94 \mathrm{Da})$ is a common form of Chls $c$. Its absorption peak wavelengths in $90 \%$ acetone are 442 and $630 \mathrm{~nm}$. There are three absorption peak wavelengths in pure diethyl ether and acetone, which are 444, 577, $626 \mathrm{~nm}$ and 447, 579, $629 \mathrm{~nm}$, respectively (Fawley 1989).

Chl $c_{2}$ (molecular formula: $\mathrm{C}_{35} \mathrm{H}_{28} \mathrm{O}_{5} \mathrm{~N}_{4} \mathrm{Mg}$; molecular mass: $608.92 \mathrm{Da}$ ) is the most common form of Chls $c$. Its absorption peak wavelengths in $90 \%$ acetone are 444 and $630 \mathrm{~nm}$. The absorption peak wavelengths in pure diethyl ether and acetone are 447, 580, $627 \mathrm{~nm}$ and 450, 581, $629 \mathrm{~nm}$, respectively (Fawley 1989).

Chl $c_{3}$ (molecular formula: $\mathrm{C}_{36} \mathrm{H}_{28} \mathrm{O}_{7} \mathrm{~N}_{4} \mathrm{Mg}$; molecular mass: $652.93 \mathrm{Da}$ ) is a form of $\mathrm{Chl} c$ found in the microalga Emiliania huxleyi (Fookes and Jeffrey 1989). Its absorption peak wavelengths in diethyl ether and acetone are 452, 585, $625 \mathrm{~nm}$ and 452, 585, $627 \mathrm{~nm}$, respectively (Fawley 1989).
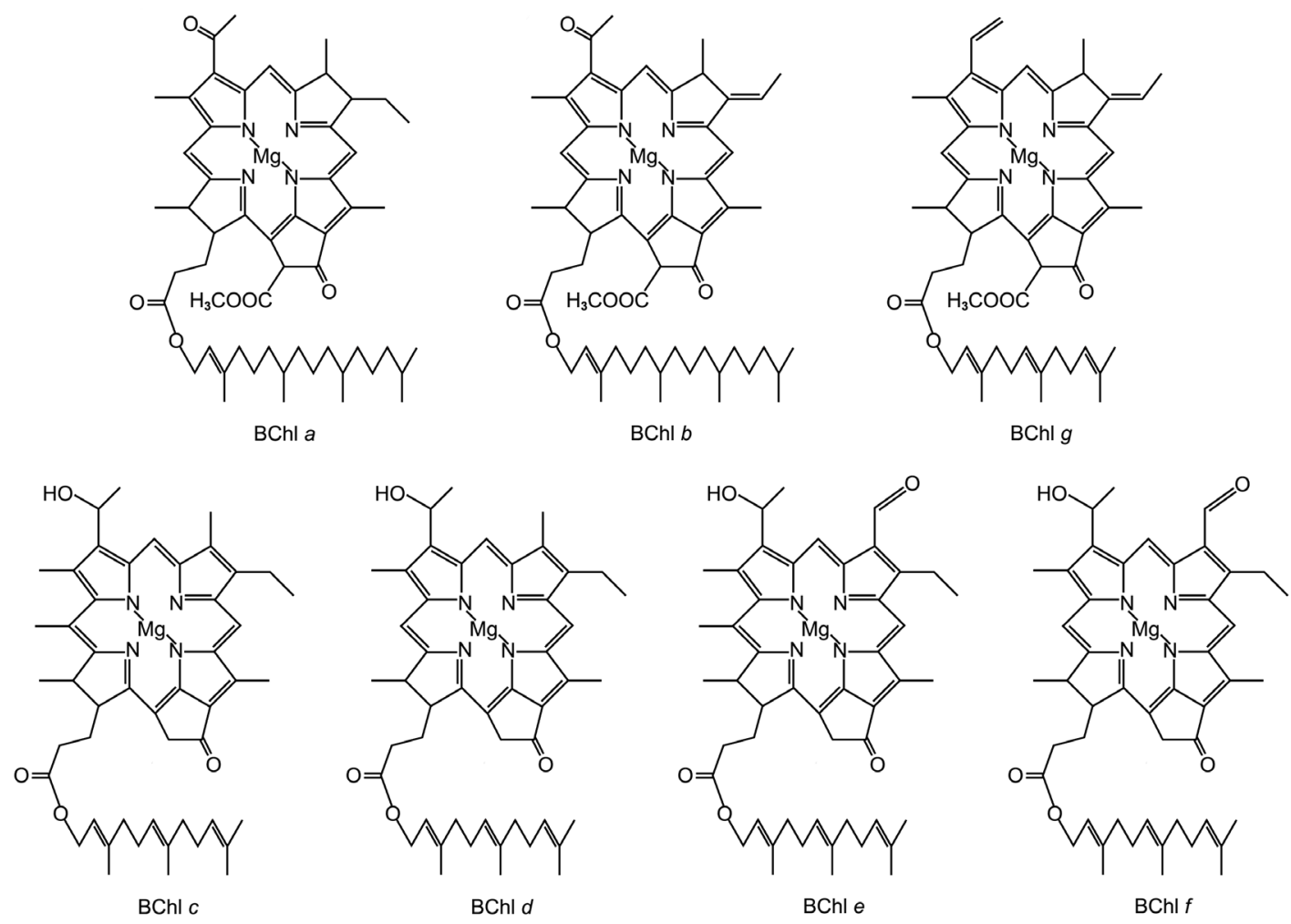

Fig. 5. The structures of bacteriochlorophylls $a, b, c, d, e, f$, and $g$. 
Chl $\boldsymbol{d}$ and Chl $f$ : Both Chl $d$ and Chl $f$ are yellow-green. Chl $d$ (molecular formula: $\mathrm{C}_{54} \mathrm{H}_{70} \mathrm{O}_{6} \mathrm{~N}_{4} \mathrm{Mg}$; molecular mass: 895.5 Da) has now been identified as the major pigment in several oxygenic prokaryotes, including Acaryochloris marina (Miyashita et al. 1997). Red algae do not have Chl $d$; the source of this was determined to be contaminating Acaryochloris attached to the surface of the red alga (Manning and Strain 1943). The absorption peak wavelengths of Chl $d$ in $90 \%$ acetone are 401, 455, and $696 \mathrm{~nm}$ (Chen 2014). Chl $d$ can absorb longer wavelengths of far-red light and shorter wavelengths of violet-blue light compared with those by Chls $a, b$, and $c$. Due to the strong transmission of far-red light in water, photosynthetic organisms containing $\mathrm{Chl} d$ are suitable for living in the water layers with overlying organisms living on Chl $a$ photosynthesis, where it can use far-red light (up to $710 \mathrm{~nm}$ in wavelength) for photosynthesis (Larkum and Kühl 2005). There is a layer of Chl $a$-containing organisms in the shallow water. So there is very little red light below due to the absorption by $\mathrm{Chl} a$, while far-red light is still present. Under these conditions, $\mathrm{Chl} d$ is favorable for photosynthesis. In the past, only $\mathrm{Chl} a$ was thought to be indispensable for energy transduction in the RCs (Björn et al. 2009), until Chl $d$ was shown to constitute up to $99 \%$ of all chlorophylls in the cyanobacterium Acaryochloris marina. In this cyanobacterium, Chl $d$ can replace $\mathrm{Chl} a$ in the RCs, harvesting excited state energy from the lightharvesting complex (Kühl et al. 2007, Allakhverdiev et al. 2016). There is a Chl $a$ monomer in PSI that participates in electron transport. Chl $d$ is likely involved in electron transport in A. marina.

Chl $f$ (molecular formula: $\mathrm{C}_{55} \mathrm{H}_{70} \mathrm{O}_{6} \mathrm{~N}_{4} \mathrm{Mg}$; molecular mass: $907.46 \mathrm{Da})$ was discovered from cyanobacteria (Chen et al. 2010, Gan et al. 2014), which has the most redshifted absorption among all Chls because of the formyl group at C-2 of Chl $f$ (Garg et al. 2017). The absorption peak wavelengths of $\mathrm{Chl} f$ in methanol are 407 and $706 \mathrm{~nm}$. Its absorption spectrum is extended to the near-infrared region (Chen and Blankenship 2011). Although there is almost no visible light in the stromatolites, cyanobacteria can also perform photosynthesis.

Pheophytin (Pheo): Pheo $a$ is demetallated Chl $a$ that serves as the first electron carrier in the PSII RC in plants. Demetallation of Chl $a$ easily occurs under acidic conditions. The absorption peak wavelength of Pheo $a$ in the red region is $665 \mathrm{~nm}$ in $90 \%$ acetone. Pheo $a$ was first postulated to be the primary electron acceptor in PSII by Van Gorkom (1974). Subsequently, the presence of two Pheo $a$ molecules in the RC of PSII was established, and one of them was shown to function as the primary electron acceptor (Hastings et al. 1992, Klimov 2003). In addition to the controversy in $A$. marina (Pheo $d$ may be the primary acceptor in $A$. marina.), the primary electron donor of PSII in other oxygenic photosynthetic organisms is Pheo $a$. While bacteriopheophytin $a$ (BPheo $a$ ) is found in the RCs of almost all purple bacteria and green filamentous bacteria, it functions as an intermediary electron acceptor. Other purple bacteria, whose major pigment is BChl $b$, use BPheo $b$ as they all employ type-2 RCs
(Kobayashi et al. 2006).

Bacteriochlorophyll (BChls): BChls are distributed in various photosynthetic bacteria and are capable of absorbing longer wavelength red light and shorter wavelength near ultraviolet light than other chlorophylls. With an absorption wavelength range of 350-1050 nm of BChls, photosynthetic bacteria can carry on photosynthesis by absorbing light energy that cannot be absorbed by higher plants or green algae (Chew and Bryant 2007, Larkum et al. 2018). For example, the absorption peak wavelengths of BChl $a$ in ethanol are 367 and $770 \mathrm{~nm}$, and that of BChl $b$ are 373 and $795 \mathrm{~nm}$ (Croce and van Amerongen 2014).

\section{Biosynthesis of chlorophyll}

Biosynthesis of metabolic precursors: In recent years, new progress has been made in several investigations of chlorophyll biosynthesis, which are the focus of this section. The synthesis of chlorophylls in organisms begins with the synthesis of $\delta$-aminolevulinic acid (ALA). ALA can be synthesized in two pathways, the C5 pathway utilizing glutamate/2-oxoglutarate and the $\mathrm{C} 4+\mathrm{C} 1$ pathway utilizing succinate and glycine (Porra 1997). And then protoporphyrin IX (Proto-IX) is synthesized from eight molecules of ALA by six enzymes. The synthesis of ALA and Proto-IX has been reviewed comprehensively in the articles by Beale $(2005,2006)$. Proto-IX is the metabolic precursor of all Chls, BChls, heme, and heme derivatives, such as the chromophores (phycobilins) of the phycobilisomes (Chew and Bryant 2007).

Mg-chelatase (a multisubunit enzyme) catalyzes the insertion of $\mathrm{Mg}^{2+}$ into Proto-IX to form Mg-Proto-IX, which is the first committed step in Chl biosynthesis (Walker and Willows 1997, Bollivar 2006, Tamiaki et al. 2016). This reaction takes place in two ATP-dependent steps, activation and chelation, and requires the hydrolysis of about 15 ATP per inserted $\mathrm{Mg}$ by $\mathrm{Mg}$-chelatase (Reid and Hunter 2004). Mg-Proto-IX is subsequently methylated to form Mg-Proto-IX-monomethylester by Mg-proto-IX methyltransferase (ChlM or BchM). Then, the propionic acid chain at $\mathrm{C}-13$ is oxidized and cyclized to form an isopentanone fifth ring (E ring) by $\mathrm{Mg}$-proto-IX monomethylester cyclase (BchE or ChlA). The product of this step is DV-PChlide $a$ (Willows 2003). All Chls and BChls are biosynthesized from DV-PChlide $a$ by a series of enzymes (Fig. 6). ChlA is an oxygen-dependent, diiron oxygenase found in the organisms that synthesizes Chls in oxic environments, whose catalytic subunit is termed the aerobic cyclization system Fe-containing subunit (AcsF) (Pinta et al. 2002). BchE is an oxygen-sensitive, radicalSAM enzyme found in the organisms that live in anoxic environments. Some purple bacteria have both ChlA and BchE, and they live in anoxic and microaerophilic conditions (Oh et al. 2000).

The next step of chlorophyll biosynthesis includes two pathways (Fig. 6). One pathway is to reduce the C-17/C-18 double bond on the pyrrole ring $\mathrm{D}$ of DV-PChlide to produce 8 -vinyl-chlorophyllide $a$ (8V-Chlide $a)$ by protochlorophyllide oxidoreductases (PORs), and then 

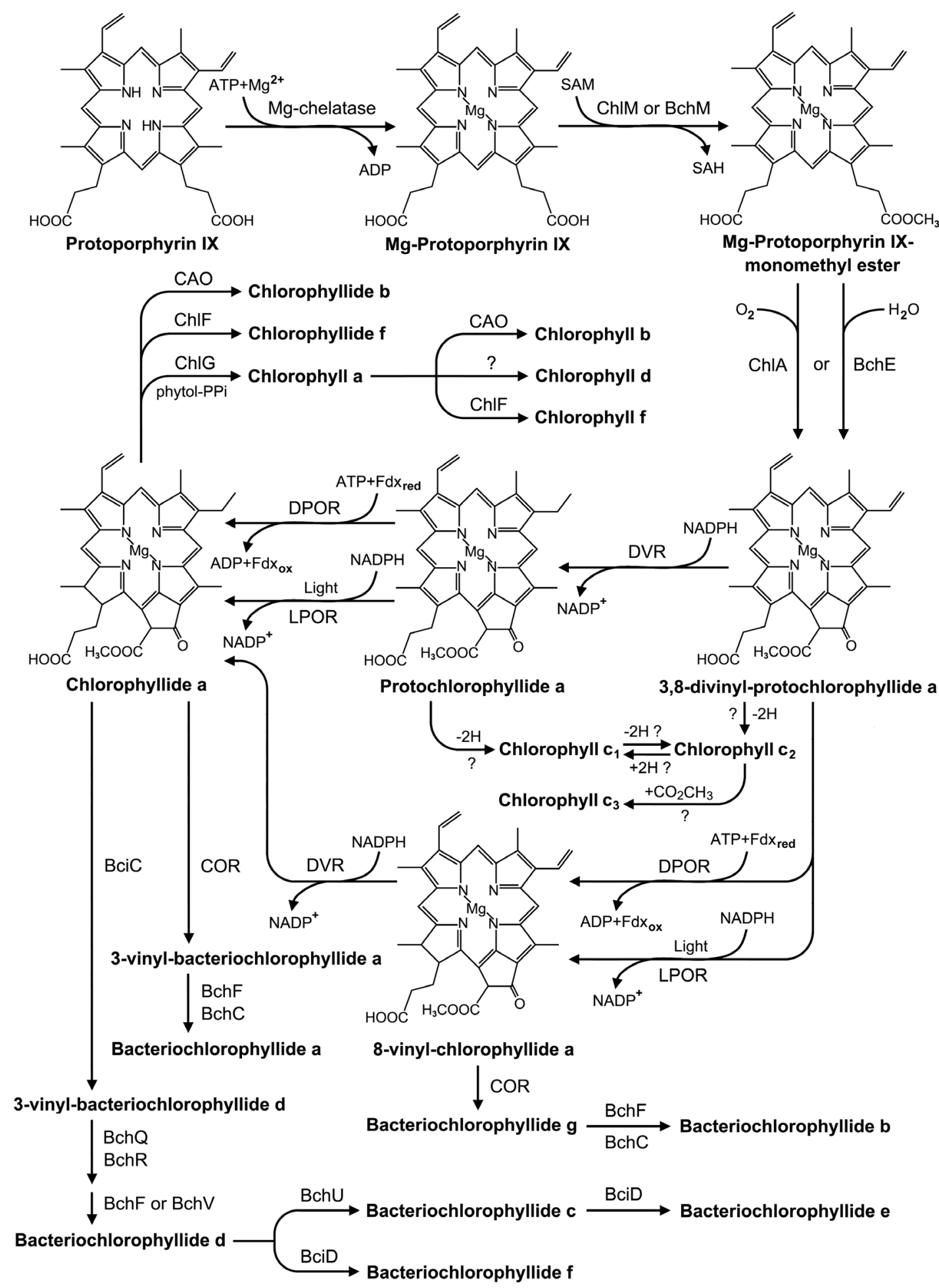

Fig. 6. The biosynthesis pathway of chlorophyllides and bacteriochlorophyllides from Protoporphyrin IX.

reduce the $\mathrm{C}-8$ vinyl group of $8 \mathrm{~V}$-Chlide $a$ to produce chlorophyllide $a$ (Chlide $a$ ) by divinyl reductases (DVRs) (Tsukatani et al. 2013a). Three members of DVRs have been discovered, namely BciA, BciB, and chlorophyllide $a$ oxidoreductase (COR) (Harada et al. 2014). Another pathway is to reduce the $\mathrm{C}-8$ vinyl group to produce
PChlide $a$ by DVRs first (Saunders et al. 2013), and then the $\mathrm{C}-17 / \mathrm{C}-18$ double bond of PChlide $a$ is reduced to produce Chlide $a$ (Wang et al. 2010). Studies have shown that the preferred substrates for both pathways of DVRs are $8 \mathrm{~V}$-Chlide $a$, with DV-PChlide being reduced only under conditions in which this pigment accumulates as 
a result of the alternative formation of Chlide $a$ (Canniffe et al. 2014).

There are two structurally unrelated PORs found in photosynthetic organisms, light-dependent protochlorophyllide oxidoreductase (LPOR) and dark-operative protochlorophyllide oxidoreductase (DPOR) (Suzuki and Bauer 1995). LPOR only has one nuclear-encoded subunit, which needs light to operate and is ubiquitously distributed in cyanobacteria and all eukaryotic photosynthetic organisms (Heyes et al. 2006). In contrast, DPOR is a protein complex composed of three subunits ( $\mathrm{L}, \mathrm{B}$, and $\mathrm{N})$, which is ubiquitously distributed in prokaryotic photosynthetic organisms and some eukaryotic photosynthetic organisms except angiosperms (Chen 2014). DPOR catalysis depends on ATP and dithionite or reduced ferredoxin (Nomata et al. 2006), which is highly sensitive to free oxygen and is deactivated when the concentration of free oxygen exceeds 3\% (Yamazaki et al. 2006). Angiosperms do not have the DPOR-encoding genes, so the conversion of PChlide $a$ to Chlide $a$ is light-dependent in angiosperm plants, and such plants are etiolated if grown in darkness. PChlide exists mostly in the complex form with proteins in etioplast, which mainly absorbs near-red and blue-violet light and has strong fluorescence properties. However, under light conditions, PChlide acts as a photosensitizer, forming highly toxic free radicals. Hence, plants need an efficient mechanism of regulating the content of PChlide. Angiosperms can regulate the PChlide content at the synthetic step of ALA (Melkozernov and Blankenship 2006).

Biosynthesis of Chls and BChls: Chlorophyllides (Chlides) or bacteriochlorophyllides (BChlides) are the immediate precursors of Chls and BChls, respectively. Only BChlide $b$ and $g$ are synthesized from 8V-Chlide $a$. The precursor of all other types of Chlides and BChlides is Chlide $a$ (Fig. 6, Table 1). In the last step of chlorophyll biosynthesis, chlorophyll synthases esterify Chlides (or BChlides) with phytyl-pyrophosphate (or farnesyl-pyrophosphate) and produce Chls (or BChls).

Biosynthesis of Chl $\boldsymbol{a}, \mathbf{C h l} \boldsymbol{b}$, and Chl $\boldsymbol{d}$ : Chlide $b$ is synthesized through the oxidation of the methyl group at C-7 of Chlide $a$ to a formyl group by chlorophyll $a$

Table 1. Chemical reactions in the synthesis of chlorophylls (Chls) and bacteriochlorophylls (BChls). $\mathrm{R}_{1}$ can be ethyl, propyl, isobutyl or neopentyl; and $\mathrm{R}_{2}$ can be methyl or ethyl (Glaeser et al. 2002, Frigaard et al. 2003, 2006).

\begin{tabular}{|c|c|c|c|c|c|c|}
\hline Substrate & Site & Substrate group & Product group & Enzyme & Product & References \\
\hline $\begin{array}{l}\text { Chl } a \\
\text { Chlide } a\end{array}$ & $\mathrm{C}-7$ & $-\mathrm{CH}_{3}$ & $-\mathrm{CHO}$ & $\mathrm{CAO}$ & $\begin{array}{l}\text { Chl } b \\
\text { Chlide } b\end{array}$ & $\begin{array}{l}\text { Tanaka et al. 1998, } \\
\text { Tanaka and Tanaka } 2011\end{array}$ \\
\hline Chl $a$ & $\mathrm{C}-3$ & $-\mathrm{CH}=\mathrm{CH}_{2}$ & $-\mathrm{CHO}$ & unknown & Chl $d$ & Schliep et al. 2010 \\
\hline $\begin{array}{l}\text { Chl } a \\
\text { Chlide } a\end{array}$ & $\mathrm{C}-2$ & $-\mathrm{CH}_{3}$ & $-\mathrm{CHO}$ & ChlF & $\begin{array}{l}\text { Chl } f \\
\text { Chlide } f\end{array}$ & $\begin{array}{l}\text { Ho et al. } 2016 \text {, } \\
\text { Li and Bridwell-Rabb } 2019\end{array}$ \\
\hline Chlide $a$ & $\mathrm{C}-7,8$ & $\mathrm{C}=\mathrm{C}$ & $\mathrm{C}-\mathrm{C}$ & COR & 3V-BChlide $a$ & Nomata et al. 2006 \\
\hline 3V-BChlide $a$ & $\mathrm{C}-3$ & $-\mathrm{CH}=\mathrm{CH}_{2}$ & $-\mathrm{COCH}_{3}$ & $\mathrm{BchF}, \mathrm{BchC}$ & BChlide $a$ & $\begin{array}{l}\text { Porra et al. } 1996, \\
\text { Lange et al. } 2015\end{array}$ \\
\hline 8V-Chlide $a$ & $\begin{array}{l}\text { C-8 } \\
\text { C-7, } 8\end{array}$ & $\begin{array}{l}-\mathrm{CH}=\mathrm{CH}_{2} \\
\mathrm{C}=\mathrm{C}\end{array}$ & $\begin{array}{l}=\mathrm{CHCH}_{3} \\
\mathrm{C}-\mathrm{C}\end{array}$ & COR & BChlide $g$ & Tsukatani et al. 2013a,b \\
\hline BChlide $g$ & $\mathrm{C}-3$ & $-\mathrm{CH}=\mathrm{CH}_{2}$ & $-\mathrm{COCH}_{3}$ & $\mathrm{BchF}, \mathrm{BchC}$ & BChlide $b$ & $\begin{array}{l}\text { Bollivar et al. } 1994, \\
\text { Suzuki et al. } 1997\end{array}$ \\
\hline Chlide $a$ & $\mathrm{C}-13^{2}$ & $-\mathrm{COOCH}_{3}$ & $-\mathrm{H}$ & BciC & 3V-BChlide $d$ & $\begin{array}{l}\text { Liu and Bryant 2011, } \\
\text { Teramura et al. 2016a }\end{array}$ \\
\hline 3V-BChlide $d$ & $\begin{array}{l}\mathrm{C}-8 \\
\mathrm{C}-12 \\
\mathrm{C}-3\end{array}$ & $\begin{array}{l}-\mathrm{CH}_{2} \mathrm{CH}_{3} \\
-\mathrm{CH}_{3} \\
-\mathrm{CH}=\mathrm{CH}_{2}\end{array}$ & $\begin{array}{l}\mathrm{R}_{1} \\
\mathrm{R}_{2} \\
-\mathrm{CH}(\mathrm{OH}) \mathrm{CH}_{3}\end{array}$ & $\begin{array}{l}\text { BchQ } \\
\text { BchR } \\
\text { BchF or BchV }\end{array}$ & BChlide $d$ & $\begin{array}{l}\text { Chew et al. } 2007, \\
\text { Frigaard et al. } 2003 \text {, } \\
\text { Teramura et al. } 2016 \mathrm{~b}\end{array}$ \\
\hline BChlide $d$ & $\mathrm{C}-7$ & $-\mathrm{CH}_{3}$ & $-\mathrm{CHO}$ & BciD & BChlide $f$ & Thweatt et al. 2017 \\
\hline BChlide $d$ & $\mathrm{C}-20$ & $-\mathrm{H}$ & $-\mathrm{CH}_{3}$ & $\mathrm{BchU}$ & BChlide $c$ & $\begin{array}{l}\text { Maresca et al. } 2004, \\
\text { Harada et al. } 2005\end{array}$ \\
\hline BChlide $c$ & $\mathrm{C}-7$ & $-\mathrm{CH}_{3}$ & $-\mathrm{CHO}$ & BciD & BChlide $e$ & Thweatt et al. 2017 \\
\hline \multicolumn{2}{|c|}{ Chlorophyll synthase } & \multicolumn{3}{|l|}{ Substrate } & Product & References \\
\hline \multicolumn{2}{|l|}{ ChlG } & \multicolumn{3}{|c|}{ Chlide $a, b+$ phytyl-pyrophosphate } & Chl $a, b$ & Chen 2014 \\
\hline \multicolumn{2}{|l|}{ BchG } & \multicolumn{3}{|c|}{ BChlide $a, b+$ phytyl-pyrophosphate } & BChl $a, b$ & Garcia-Gil et al. 2003 \\
\hline \multicolumn{2}{|l|}{ BchG } & \multicolumn{3}{|c|}{ BChlide $g+$ farnesyl-pyrophosphate } & BChl $g$ & Chew and Bryant 2007 \\
\hline \multicolumn{2}{|l|}{ BchK } & \multicolumn{3}{|c|}{ BChlide $c, d, e, f+$ farnesyl-pyrophosphate } & $\mathrm{BChl} c, d, e, f$ & Frigaard et al. 2002 \\
\hline
\end{tabular}


oxygenase (CAO) (Tanaka et al. 1998, Tanaka and Tanaka 2011, Tsuchiya et al. 2012, Li and Bridwell-Rabb 2019). Chlide $a$ and $b$ are esterified with phytyl-pyrophosphate by ChlG (Chl specific synthase) to form Chl $a, b$ (Chen 2014). Experiments have validated that $\mathrm{Chl} a$ is the biosynthetic precursor of $\mathrm{Chl} d$, and that the formyl group at C-3 of Chl $d$ is formed via an oxidative reaction (Schliep et al. 2010, Chen 2014). However, the related enzymes that convert Chl $a$ to $\mathrm{Chl} d$ are yet to be discovered.

Biosynthesis of Chl $c$ : Based on molecular structure similarities, Bogorad (1976) first suggested that PChlide and DV-PChlide may be the biosynthetic precursors of $\mathrm{Chl} c_{1}$ and $\mathrm{Chl} c_{2}$, respectively. Beale first proposed the biosynthetic relationship between DV-PChlide, PChlide, Chl $c_{1}$, and Chl $c_{2}$ (Beale 1984). Porra (1997) suggested that $\mathrm{Chl} c_{3}$ is synthesized from $\mathrm{Chl} c_{2}$. The formation of the 7-methylcarboxylate group of $\mathrm{Chl} c_{3}$ involves 7-formyl group formation by an oxygenase, as in $\mathrm{Chl} b$ biosynthesis. Unlike Chl $a$ and $\mathrm{Chl} b$, the enzymic mechanisms involved in the biosynthesis of the $\mathrm{Chl} c$ group are still poorly understood until now.

Biosynthesis of Chl $f$ : The molecular structure of Chl $f$ has been confirmed to be 2-formylated Chl $a$ (Willows et al. 2013). Experiments show that the synthesis of Chl $f$ is light-dependent, which implies that Chl $f$ synthase (ChlF) is the photooxidoreductase that oxidizes Chl $a$ (or Chlide $a$ ) to form Chl $f$ (or Chlide $f$ ) (Ho et al. 2016, Li and Bridwell-Rabb 2019). The oxygen atom in the C-2-formyl group on Chl $f$ originates from molecular oxygen instead of water (Garg et al. 2017).

Biosynthesis of BChl $\boldsymbol{a}$ : The first step of synthesis of BChl $a$ from Chlide $a$ is the reduction of the double bond between the C-7 and C- 8 carbons of Chlide $a$ by COR to produce 3-vinyl-bacteriochlorophyllide $a$ (3V-BChlide $a$ ) (Nomata et al. 2006). COR is composed of three subunits: $\mathrm{BchX}, \mathrm{BchY}$, and $\mathrm{BchZ}$. BchX is assumed to be the electron-donating component. BchY and BchZ would play a role as the catalytic, substrate-binding proteins (Nomata et al. 2006, Tsukatani et al. 2013a, 2015). The C-3 vinyl group of $3 \mathrm{~V}$-BChlide $a$ is then hydrated by BchF enzyme to introduce a $\mathrm{C}-3^{1}$-hydroxyl group (Porra et al. 1996). This hydration reaction is followed by dehydrogenation on the $\mathrm{C}-3$ side chain by the BchC enzyme to form the $\mathrm{C}-3$-acetyl group, and the product is BChlide $a$ (Bollivar et al. 1994, Lange et al. 2015). The final step in BChl $a$ biosynthesis is the addition of a phytyl 'tail' to BChlide $a$ by BchG, a BChl $a$-specific synthase (Addlesee et al. 2000, Garcia-Gil et al. 2003).

Biosynthesis of BChl $\boldsymbol{b}$ and BChl $\boldsymbol{g}$ : BChl $b$ and $g$ have an ethylidene group at the $\mathrm{C}-8$ position. The COR enzymes (BvCOR or HmCOR) simultaneously catalyze the $\mathrm{C}$-8-vinyl and $\mathrm{C} 7=\mathrm{C} 8$ double bond of $8 \mathrm{~V}$-Chlide $a$ to form $\mathrm{C}$-8-ethylidene $\left(\mathrm{CH}_{3} \mathrm{CH}=\right)$, producing BChlide $g$ (Tsukatani et al. 2013a,b). Similar to the synthesis of BChlide $a$ from $3 \mathrm{~V}$-BChlide $a$, the C-3 vinyl group of BChlide $g$ can be catalyzed by the BchF enzyme and BchC enzyme to form a C-3-acetyl group through hydration and dehydrogenation, producing BChlide $b$ (Bollivar et al. 1994, Suzuki et al. 1997). Based on genome information, $\mathrm{BchF}$ and $\mathrm{BchC}$ gene are also present in $\mathrm{BChl} b$-producing bacteria. The ethylidene formation, therefore, has been thought to occur on BChlide $a$ to form BChlide $b$ (Tsukatani et al. 2013a). Finally, BChlide $b$ and BChlide $g$, respectively, add a phytol and a farnesyl 'tail' by the synthase BchG to form Bchl $b$ and Bchl $g$ (Chew and Bryant 2007).

Biosynthesis of $\mathrm{BChl} c, d, e$, and $f$ : In the biosynthesis of $\mathrm{BChl} c, d, e$, and $f$, the $\mathrm{C} 13^{2}$-methoxycarbonyl group is removed by the BciC enzyme first. After the $\mathrm{C}-13^{2}$-methoxycarbonyl group of Chlide $a$ is removed by the BciC enzyme, 3-vinyl-bacteriochlorophyllide $d$ (3V-BChlide $d$ ) is formed (Liu and Bryant 2011, Teramura et al. 2016a). Then, the BchF or BchV enzyme hydrates the $\mathrm{C}-3$ vinyl group to introduce the $\mathrm{C}-3^{1}$-hydroxyl group to form BChlide $d$ (Harada et al. 2015, Teramura et al. 2016b). BChlide $d$ is the biosynthetic precursor of BChlide $c$ and $e$.

The naturally occurring BChlide $c, d$, and $e$ have multiple homologs that carry different side chains at the C- 8 and C-12 positions. During the synthesis of BChlide $d$ by $3 \mathrm{~V}$-BChlide $d$, these different side chains arise from methylation using S-adenosylmethionine (SAM) as the methyl donor (Huster and Smith 1990). Two types of chlorophyll methyltransferases have been found in bacteria, BchQ and BchR, which add the methyl groups to the $\mathrm{C}-8^{2}$ ethyl carbon and $\mathrm{C}-12^{1}$ methyl carbon, respectively. Up to three methyl groups can be added at $\mathrm{C}-8^{2}$, and only one methyl group can be added at C-12 ${ }^{1}$. Hence, the C-8 side chain can be ethyl, propyl, isobutyl or neopentyl, and the C-12 side chain can be methyl or ethyl (Glaeser et al. 2002, Frigaard et al. 2003, 2006). Methylation of the $\mathrm{C}-8$ and $\mathrm{C}-12$ side chains does not affect the absorbance properties of BChl $c$ (Frigaard et al. 2003, Chew et al. 2007).

BChlide $d$ can be converted to BChlide $c$ by transferring a methyl to the C-20 methine bridge position of BChlide $d$. The enzyme that catalyzes this step is BchU methyltransferase (Maresca et al. 2004, Harada et al. 2005). The methyl group at the C-7 position of BChlide $c$ is oxidized by a radical SAM enzyme, BciD, to form the formyl group by which to form BChlide $e$. BChlide $d$ can be converted to BChlide $f$ through the same reaction by the BciD enzyme (Thweatt et al. 2017). The last specific synthase in the biosynthesis of $\mathrm{BChl} c, d, e$, and $f$ is $\mathrm{BchK}$, which adds the farnesyl 'tail' to BChlide $c, d$, $e$, and $f$ (Frigaard et al. 2002). In addition to the phytol 'tail' and farnesol 'tail', there are other esterifying alcohols in certain BChls, such as geranylgeranyl, dihydrogeranylgeranyl, and tetrahydrogeranylgeranyl (Frigaard et al. 2002, Glaeser et al. 2002, Tsukatani et al. 2015).

\section{Conclusion}

More than one hundred species of chlorophylls are known in photosynthetic organisms today. The structures of the 
'head' of all Chls and BChls are very similar, and there is no significant characteristic difference between the two types of chlorophylls, indicating that the 'head' is necessary for photosynthesis. Most of Chls and BChls involved in light harvesting carry an ethyl group at the C-8 position of the chlorophyll molecule (Canniffe et al. 2014). Different photosynthetic organisms change the light absorption spectrum by changing the single and double bonds or the side chain on the 'head', generating functional diversity for solar energy capture and conversion in phototrophs (Chew and Bryant 2007). With the exception of most $c$-type Chls, other chlorophylls have a phytol or farnesol 'tail', but the effect of 'tail' length on the properties of chlorophylls remains unclear. The stereochemistry structure of chlorophyll is helpful for understanding the function and properties of chlorophyll (Tamiaki et al. 2016, Harada et al. 2015, Teramura et al. 2016b), which is not covered in this paper. We mainly summarized the planar structure differences between the members of chlorophyll family (Figs. 1-5).

This paper also clarifies the synthesis pathways of various chlorophylls and their interrelationship (Fig. 6). DV-PChlide $a$ is the common biosynthetic precursor of all chlorophylls, and is divided into two synthetic pathways from this substrate. DV-PChlide $a$ is converted to $8 \mathrm{~V}$-Chlide $a$ and Chlide $a$ by different reduction reactions. $\mathrm{BCh} b$ and $g$ are synthesized from $8 \mathrm{~V}$-Chlide $a$, and the other chlorophylls are synthesized from Chlide $a$. Only the synthetic pathway of Chls $c$ is unclear. According to their structures, Chls $c$ may also be derived from DV-PChlide $a$ or PChlide $a$. Most of the steps in chlorophyll synthesis have been clarified. The enzymes involved in chlorophyll synthesis, substrates, products, catalytic sites and groups are detailed in Table 1. More chlorophylls are expected to be discovered in the future, and the biochemical pathways of chlorophyll synthesis will be fully understood. The new properties and functions of chlorophylls will be gradually revealed, helping us further understand the photosynthetic characteristics of phototrophs. This paper comprehensively reviews the biochemical processes of chlorophylls, which helps readers quickly understand the research progress of chlorophylls.

\section{References}

Addlesee H.A., Fiedor L., Hunter C.N.: Physical mapping of bch $G$, orf 427 , and orf 177 in the photosynthesis gene cluster of Rhodobacter sphaeroides: Functional assignment of the bacteriochlorophyll synthetase gene. - J. Bacteriol. 182: 3175-3182, 2000.

Allakhverdiev S.I., Kreslavski V.D., Zharmukhamedov S.K. et al.: Chlorophylls $d$ and $f$ and their role in primary photosynthetic processes of cyanobacteria. - BiochemistryMoscow+ 81: 201-212, 2016.

Allen M.B.: Distribution of chlorophylls. - In: Vernon L.P., Seely G.R. (ed.): The Chlorophylls. Pp.511-519. Academic Press, New York 1966.

Beale S.I.: Biosynthesis of photosynthetic pigments. - In: Baker N.R., Barber J. (ed.): Chloroplast Biogenesis. Pp. 135-205. Elsevier, Amsterdam 1984.

Beale S.I.: Green genes gleaned. - Trends Plant Sci. 10: 309-312, 2005.
Beale S.I.: Biosynthesis of 5-aminolevulinic acid. - In: Grimm B., Porra R.J., Rüdiger W., Scheer H. (ed.): Chlorophylls and Bacteriochlorophylls. Advances in Photosynthesis and Respiration. Pp. 147-158. Springer, Dordrecht 2006.

Bennett M.S., Triemer R.E.: Chloroplast genome evolution in the Euglenaceae. - J. Eukaryot. Microbiol. 62: 773-785, 2015.

Björkman O.: Responses to different quantum flux densities. In: Lange O.L., Nobel P.S., Osmond C.B., Ziegler H. (ed.): Physiological Plant Ecology I. Responses to the Physical Environment. Pp. 57-107. Springer-Verlag, New York 1981.

Björn L.O., Papageorgiou G.C., Blankenship R.E., Govindjee: A viewpoint: Why chlorophyll $a$ ? - Photosynth. Res. 99: $85-98,2009$

Bogorad L.: Chlorophyll biosynthesis. - In: Goodwin T.W. (ed.): Chemistry and Biochemistry of Plant Pigments. Pp. 64-148. Academic Press Inc., London 1976.

Bollivar D.W., Suzuki J.Y., Beatty J.T., Dobrowolski J.M., Bauer C.E.: Directed mutational analysis of bacteriochlorophyll $a$ biosynthesis in Rhodobacter capsulatus. - J. Mol. Biol. 237: 622-640, 1994.

Bollivar D.W.: Recent advances in chlorophyll biosynthesis. Photosynth. Res. 90: 173-194, 2006.

Brestič M., Živčák M., Kunderlíková K., Allakhverdiev S.I.: High temperature specifically affects the photoprotective responses of chlorophyll $b$ deficient wheat mutant lines. Photosyn. Res. 130: 251-266, 2016.

Canniffe D.P., Chidgey J.W., Hunter C.N.: Elucidation of the preferred routes of $\mathrm{C} 8$-vinyl reduction in chlorophyll and bacteriochlorophyll biosynthesis. - Biochem. J. 462: 433-440, 2014.

Chen M., Blankenship R.E.: Expanding the solar spectrum used by photosynthesis. - Trends Plant Sci. 16: 427-431, 2011.

Chen M., Schliep M., Willows R.D. et al.: A red-shifted chlorophyll. - Science 329: 1318-1319, 2010.

Chen M.: Chlorophyll modifications and their spectral extension in oxygenic photosynthesis. - Annu. Rev. Biochem. 83: 317-340, 2014

Chew A.G.M., Bryant D.A.: Chlorophyll biosynthesis in bacteria: The origins of structural and functional diversity. - Annu. Rev. Microbiol. 61: 113-129, 2007.

ChewA.G.M.,FrigaardN.U.,BryantD.A.:Bacteriochlorophyllide c $\mathrm{C}-8^{2}$ and $\mathrm{C}-12^{1}$ methyltransferases are essential for adaptation to low light in Chlorobaculum tepidum. J. Bacteriol. 189: 6176-6184, 2007.

Croce R., van Amerongen H.: Natural strategies for photosynthetic light harvesting. - Nat. Chem. Biol. 10: 492-501, 2014.

Eisen J.A., Nelson K.E., Paulsen I.T. et al.: The complete genome sequence of Chlorobium tepidum TLS, a photosynthetic, anaerobic, green-sulfur bacterium. - P. Natl. Acad. Sci. USA 99: 9509-9514, 2002.

Esteban R., Barrutia O., Artetxe U. et al.: Internal and external factors affecting photosynthetic pigment composition in plants: a meta-analytical approach. - New Phytol. 206: 268280, 2015

Fawley M.W.: A new form of chlorophyll $c$ involved in lightharvesting. - Plant Physiol. 91: 727-732, 1989.

Fookes C.J.R., Jeffrey S.W.: The structure of chlorophyll $c_{3}$, a novel marine photosynthetic pigment. - J. Chem. Soc. Chem. Comm. 23: 1827-1828, 1989.

Frigaard N.U., Chew A.G.M., Li H. et al.: Chlorobium tepidum: Insights into the structure, physiology, and metabolism of a green sulfur bacterium derived from the complete genome sequence. - Photosynth. Res. 78: 93-117, 2003.

Frigaard N.U., Chew A.G.M., Maresca J.A., Bryant D.A.: Bacteriochlorophyll biosynthesis in green bacteria. In: Grimm B., Porra R.J., Rüdiger W., Scheer H. (ed.): 
Chlorophylls and Bacteriochlorophylls. Advances in Photosynthesis and Respiration. Pp. 201-221. Springer, Dordrecht 2006.

Frigaard N.U., Voigt G.D., Bryant D.A.: Chlorobium tepidum mutant lacking bacteriochlorophyll $c$ made by inactivation of the $b c h K$ gene, encoding bacteriochlorophyll $c$ synthase. J. Bacteriol. 184: 3368-3376, 2002.

Gan F., Zhang S., Rockwell N.C. et al.: Extensive remodeling of a cyanobacterial photosynthetic apparatus in far-red light. Science 345: 1312-1317, 2014.

Garcia-Gil L.J., Gich F.B., Fuentes-Garcia X.: A comparative study of $b c h G$ from green photosynthetic bacteria. - Arch. Microbiol. 179: 108-115, 2003.

Garg H., Loughlin P.C., Willows R.D., Chen M.: The C2 ${ }^{1}$-formyl group in chlorophyll $f$ originates from molecular oxygen. J. Biol. Chem. 292: 19279-19289, 2017.

Glaeser J., Bañeras L., Rütters H., Overmann J.: Novel bacteriochlorophyll $e$ structures and species-specific variability of pigment composition in green sulfur bacteria. - Arch. Microbiol. 177: 475-485, 2002.

Gloe A., Pfennig N., Brockmann Jr. H., Trowitzsch W.: A new bacteriochlorophyll from brown-colored Chlorobiaceae. Arch. Microbiol. 102: 103-109, 1975.

Granick S.: The structural and functional relationships between heme and chlorophyll. - Harvey Lect. 44: 220-245, 1948.

Green B., Anderson J., Parson W.W.: Photosynthetic membranes and their light-harvesting antennas. - In: Green B., Parson W. (ed.): Light-Harvesting Antennas in Photosynthesis. Pp. 1-28. Kluwer Academic Publishers, Dordrecht 2003.

Harada J., Mizoguchi T., Tsukatani Y. et al.: Chlorophyllide $a$ oxidoreductase works as one of the divinyl reductases specifically involved in bacteriochlorophyll $a$ biosynthesis. J. Biol. Chem. 289: 12716-12726, 2014.

Harada J., Saga Y., Yaeda Y. et al.: In vitro activity of C-20 methyltransferase, BchU, involved in bacteriochlorophyll $c$ biosynthetic pathway in green sulfur bacteria. - FEBS Lett. 579: 1983-1987, 2005.

Harada J., Teramura M., Mizoguchi T. et al.: Stereochemical conversion of C3-vinyl group to 1-hydroxyethyl group in bacteriochlorophyll $c$ by the hydratases $\mathrm{BchF}$ and $\mathrm{BchV}$ : adaptation of green sulfur bacteria to limited-light environments. - Mol. Microbiol. 98: 1184-1198, 2015.

Hastings G., Durrant J.R., Barber J. et al: Observation of pheophytin reduction in photosystem two reaction centers using femtosecond transient absorption spectroscopy. Biochemistry 31: 7638-7647, 1992.

Helfrich M., Bommer B., Oster U. et al.: Chlorophylls of the $c$ family: Absolute configuration and inhibition of NADPH:protochlorophyllide oxidoreductase. - BBABioenergetics 1605: 97-103, 2003.

Heyes D.J., Heathcote P., Rigby S.E.J. et al.: The first catalytic step of the light-driven enzyme protochlorophyllide oxidoreductase proceeds via a charge transfer complex. J. Biol. Chem. 281: 26847-26853, 2006.

Ho M.Y., Shen G., Canniffe D.P. et al.: Light-dependent chlorophyll $f$ synthase is a highly divergent paralog of PsbA of photosystem II. - Science 353: aaf9178, 2016.

Huster M.S., Smith K.M.: Biosynthetic studies of substituent homologation in bacteriochlorophylls $c$ and $d$. - Biochemistry 29: 4348-4355, 1990.

Ishikita H., Saenger W., Biesiadka J. et al.: How photosynthetic reaction centers control oxidation power in chlorophyll pairs P680, P700, and P870. - P. Natl. Acad. Sci. USA 103: 98559860, 2006.

Klimov V.V.: Discovery of pheophytin function in the photosynthetic energy conversion as the primary electron acceptor of Photosystem II. - Photosynth. Res. 76: 247-253, 2003.

Kobayashi M., Akiyama M., Kise H., Watanabe T.: Unusual tetrapyrrole pigments of photosynthetic antenna and reaction centers: specially-tailored chlorophylls. - In: Grimm B., Porra R.J., Rüdiger W., Scheer H. (ed.): Chlorophylls and Bacteriochlorophylls. Advances in Photosynthesis and Respiration. Pp. 56-63. Springer, Dordrecht 2006.

Kühl M., Chen M., Larkum A.W.D.: Algae and cyanobacteria in extreme environments. - In: Seckbach J. (ed.): Cellular Origin, Life in Extreme Habitats and Astrobiology. Pp. 101123. Springer, Dordrecht 2007.

Lange C., Kiesel S., Peters S. et al.: Broadened substrate specificity of 3-hydroxyethyl bacteriochlorophyllide $a$ dehydrogenase $(\mathrm{BchC})$ indicates a new route for the biosynthesis of bacteriochlorophyll $a$. - J. Biol. Chem. 290: 19697-19709, 2015.

Larkum A.W.D., Kühl M.: Chlorophyll $d$ : the puzzle resolved. Trends Plant Sci. 10: 355-357, 2005.

Larkum A.W.D., Ritchie R.J., Raven J.A.: Living off the Sun: chlorophylls, bacteriochlorophylls and rhodopsins. Photosynthetica 56: 11-43, 2018.

Li B., Bridwell-Rabb J.: Aerobic enzymes and their radical SAM enzyme counterparts in tetrapyrrole pathways. Biochemistry 58: 85-93, 2019.

Liu Z.F., Bryant D.A.: Identification of a gene essential for the first committed step in the biosynthesis of bacteriochlorophyll c. - J. Biol. Chem. 286: 22393-22402, 2011.

Manning W.M., Strain H.H.: Chlorophyll $d$, a green pigment of red algae. - J. Biol. Chem. 151: 1-19, 1943.

Maresca J.A., Chew A.G.M., Ponsatí M.R. et al.: The bchU gene of Chlorobium tepidum encodes the bacteriochlorophyll C-20 methyltransferase. - J. Bacteriol. 186: 2558-2566, 2004.

Melkozernov A.N., Blankenship R.E.: Photosynthetic functions of chlorophylls. - In: Grimm B., Porra R.J., Rüdiger W., Scheer H. (ed.): Chlorophylls and Bacteriochlorophylls. Advances in Photosynthesis and Respiration. Pp. 397-410. Springer, Dordrecht 2006.

Miyashita H., Adachi K., Kurano N. et al.: Pigment composition of a novel oxygenic photosynthetic prokaryote containing chlorophyll $d$ as the major chlorophyll. - Plant Cell Physiol. 38: 274-281, 1997.

Moss G.P.: Nomenclature of tetrapyrroles. IUPAC-IUB Joint Commission on Biochemical Nomenclature (JCBN). Recommendations 1986. - Eur. J. Biochem. 178: 277-328, 1988.

Niedzwiedzki D.M., Blankenship R.E.: Singlet and triplet excited state properties of natural chlorophylls and bacteriochlorophylls. - Photosynth. Res. 106: 227-238, 2010.

Nomata J., Mizoguchi T., Tamiaki H., Fujita Y.: A second nitrogenase-like enzyme for bacteriochlorophyll biosynthesis: reconstitution of chlorophyllide $a$ reductase with purified X-protein (BchX) and YZ-protein (BchY-BchZ) from Rhodobacter capsulatus. - J. Biol. Chem. 281: 15021-15028, 2006.

Oh J.I., Eraso J.M., Kaplan S.: Interacting regulatory circuits involved in orderly control of photosynthesis gene expression in Rhodobacter sphaeroides 2.4.1. - J. Bacteriol. 182: 30813087, 2000.

Pinta V., Picaud M., Reiss-Husson F., Astier C.: Rubrivivax gelatinosus acsF (previously orf358) codes for a conserved, putative binuclear-iron-cluster-containing protein involved in aerobic oxidative cyclization of Mg-protoporphyrin IX monomethylester. - J. Bacteriol. 184: 746-753, 2002.

Porra R.J., Schäfer W., Gad'on N. et al.: Origin of the two carbonyl oxygens of bacteriochlorophyll $a$ : Demonstration of two different pathways for the formation of ring $\mathrm{E}$ in Rhodobacter 
sphaeroides and Roseobacter denitrificans, and a common hydratase mechanism for 3-acetyl group formation. - Eur. J. Biochem. 239: 85-92, 1996.

Porra R.J.: Recent progress in porphyrin and chlorophyll biosynthesis. - Photochem. Photobiol. 65: 492-516, 1997.

Raven P.H., Evert R.F., Eichhorn S.E.: Photosynthesis, light, and life. - In: Biology of Plants ( $7^{\text {th }}$ Edition). Pp. 119-127. W.H. Freeman and Company Publishers, New York 2005.

Reid J.D., Hunter C.N.: Magnesium-dependent ATPase activity and cooperativity of magnesium chelatase from Synechocystis sp. PCC6803. - J. Biol. Chem. 279: 26893-26899, 2004.

Saunders A.H., Golbeck J.H., Bryant D.A.: Characterization of BciB: A ferredoxin-dependent 8-vinyl-protochlorophyllide reductase from the green sulfur bacterium Chloroherpeton thalassium. - Biochemistry 52: 8442-8451, 2013.

Scheer H.: An overview of chlorophylls and bacteriochlorophylls: Biochemistry, biophysics, functions and applications. In: Grimm B., Porra R.J., Rüdiger W., Scheer H. (ed.): Chlorophylls and Bacteriochlorophylls. Advances in Photosynthesis and Respiration. Pp. 1-19. Springer, Dordrecht 2006.

Schliep M., Crossett B., Willows R.D., Chen M.: ${ }^{18} \mathrm{O}$ labeling of chlorophyll $d$ in Acaryochloris marina reveals that chlorophyll $a$ and molecular oxygen are precursors. - J. Biol. Chem. 285: 28450-28456, 2010.

Suzuki J.Y., Bauer C.E.: A prokaryotic origin for light-dependent chlorophyll biosynthesis of plants. - P. Natl. Acad. Sci. USA 92: 3749-3753, 1995.

Suzuki J.Y., Bollivar D.W., Bauer C.E.: Genetic analysis of chlorophyll biosynthesis. - Annu. Rev. Genet. 31: 61-89, 1997.

Tamiaki H., Komada J., Kunieda M. et al.: In vitro synthesis and characterization of bacteriochlorophyll- $f$ and its absence in bacteriochlorophyll-e producing organisms. - Photosynth. Res. 107: 133-138, 2011.

Tamiaki H., Teramura M., Tsukatani Y.: Reduction processes in biosynthesis of chlorophyll molecules: chemical implication of enzymatically regio- and stereoselective hydrogenations in the late stages of their biosynthetic pathway. - B. Chem. Soc. Jpn. 89: 161-173, 2016.

Tanaka A., Ito H., Tanaka R. et al.: Chlorophyll a oxygenase $(\mathrm{CAO})$ is involved in chlorophyll $b$ formation from chlorophyll a. - P. Natl. Acad. Sci. USA 95: 12719-12723, 1998.

Tanaka R., Tanaka A.: Chlorophyll cycle regulates the construction and destruction of the light-harvesting complexes. - BBABioenergetics 1807: 968-976, 2011.

Taniguchi M., Lindsey J.S.: Synthetic chlorins, possible surrogates for chlorophylls, prepared by derivatization of porphyrins. - Chem. Rev. 117: 344-535, 2017.

Teramura M., Harada J., Mizoguchi T. et al.: In vitro assays of $\mathrm{BciC}$ showing $\mathrm{C} 13^{2}$-demethoxycarbonylase activity requisite for biosynthesis of chlorosomal chlorophyll pigments. - Plant Cell Physiol. 57: 1048-1057, 2016a.

Teramura M., Harada J., Tamiaki H.: In vitro stereospecific hydration activities of the 3-vinyl group of chlorophyll derivatives by $\mathrm{BchF}$ and $\mathrm{BchV}$ enzymes involved in bacteriochlorophyll $c$ biosynthesis of green sulfur bacteria. Photosynth. Res. 130: 33-45, 2016b.

Thweatt J.L., Ferlez B.H., Golbeck J.H., Bryant D.A.: BciD is a radical S-adenosyl-1-methionine (SAM) enzyme that completes bacteriochlorophyllide $e$ biosynthesis by oxidizing a methyl group into a formyl group at C-7. - J. Biol. Chem. 292: 1361-1373, 2017.

Tsuchiya T., Mizoguchi T., Akimoto S. et al.: Metabolic engineering of the $\mathrm{Chl} d$-dominated cyanobacterium Acaryochloris marina: Production of a novel Chl species by the introduction of the chlorophyllide $a$ oxygenase gene. Plant Cell Physiol. 53: 518-527, 2012.

Tsukatani Y., Harada J., Nomata J.et al.: Rhodobacter sphaeroides mutants overexpressing chlorophyllide $a$ oxidoreductase of Blastochloris viridis elucidate functions of enzymes in late bacteriochlorophyll biosynthetic pathways. - Sci. Rep. 5: 9741, 2015.

Tsukatani Y., Yamamoto H., Harada J. et al.: An unexpectedly branched biosynthetic pathway for bacteriochlorophyll $b$ capable of absorbing near-infrared light. - Sci Rep. 3: 1217, 2013a.

Tsukatani Y., Yamamoto H., Mizoguchi T. et al.: Completion of biosynthetic pathways for bacteriochlorophyll $g$ in Heliobacterium modesticaldum: The C8-ethylidene group formation. - BBA-Bioenergetics 1827: 1200-1204, 2013 b.

Van Gorkom H.J.: Identification of the reduced primary electron acceptor of Photosystem II as a bound semiquinone anion. BBA-Bioenergetics 347: 439-442, 1974.

Vogl K., Tank M., Orf G.S. et al.: Bacteriochlorophyllf: properties of chlorosomes containing the "forbidden chlorophyll". Front. Microbiol. 3: 298, 2012.

Walker C.J., Willows R.D.: Mechanism and regulation of Mgchelatase. - Biochem. J. 327: 321-333, 1997.

Wang P.R., Gao J.X., Wan C.M. et al.: Divinyl chlorophyll(ide) $a$ can be converted to monovinyl chlorophyll(ide) $a$ by a divinyl reductase in rice. - Plant Physiol. 153: 994-1003, 2010.

Willows R.D.: Biosynthesis of chlorophylls from protoporphyrin IX. - Nat. Prod. Rep. 20: 327-341, 2003.

Willows R.D., Li Y., Scheer H., Chen M.: Structure of chlorophyll $f$. - Org. Lett. 15: 1588-1590, 2013.

Xu M., Kinoshita Y., Matsubara S., Tamiaki H.: Synthesis of chlorophyll- $c$ derivatives by modifying natural chlorophyll- $a$.Photosynth. Res. 127: 335-345, 2016.

Yamazaki S., Nomata J., Fujita Y.: Differential operation of dual protochlorophyllide reductases for chlorophyll biosynthesis in response to environmental oxygen levels in the cyanobacterium Leptolyngbya boryana. - Plant Physiol. 142: 911-922, 2006.

Zapata M., Garrido J.L., Jeffrey S.W.: Chlorophyll $c$ pigments: Current status. - In: Grimm B., Porra R.J., Rüdiger W., Scheer H. (ed.): Chlorophylls and Bacteriochlorophylls. Advances in Photosynthesis and Respiration. Pp. 40-50. Springer, Dordrecht 2006.

(C) The authors. This is an open access article distributed under the terms of the Creative Commons BY-NC-ND Licence. 